Natural Hazards and Earth System Sciences, 5, 911-923, 2005

SRef-ID: 1684-9981/nhess/2005-5-911

European Geosciences Union

(C) 2005 Author(s). This work is licensed

under a Creative Commons License.

\title{
Locating hidden river courses via geo-technical investigation - application in the city of Granada, Spain
}

\author{
J. C. Hernández del Pozo, I. Ocete, R. García, and R. Carmona \\ Deparment of Civil Engineering, Higher Technical College, Roads, Canals y Ports, University of Granada, Polytechnical \\ Building, Fuentenueva Campus, 18071 Granada, Spain
}

Received: 5 April 2005 - Revised: 30 September 2005 - Accepted: 30 September 2005 - Published: 11 November 2005

\begin{abstract}
The diversion of natural river courses and subsequent filling by alluvial deposits or anthropic intervention has been hidden by urban development in the majority of the cities. The research we conducted involved monitoring the evolution of a river course and reconnaissance of the original morphology of the fluvial systems. Our research was applied to the section of the River Beiro that flows through the city of Granada, Spain. The research has been carried out using geo-technical methodology based on reconnaissance via dynamic penetration. This allowed us to determine the different degrees of consolidation and compaction in the areas corresponding with the former course of the river, which are now filled by alluvial deposits. In addition, we have backed up our findings with information provided by historical maps of the city of Granada. The results have identified an area wherein buildings are at risk, as evidenced by the detrimental effects registered in the buildings in this area.
\end{abstract}

\section{Introduction}

River courses that have been recently filled by alluvial deposits are often areas with considerable geotechnical impact, mainly due to the detrimental effect on the buildings constructed on this type of terrain. As a consequence of their recent formation, these alluvial deposits have little or no consolidation, generally have high water table levels and are unable to support heavy loads (Velázquez, 1995). Obviously these alluvial deposits do not coincide with the current course of the river: over the years, river courses are diverted due to natural causes or as a result of the elimination of meanders by anthropic intervention. In heavily built up urban areas with a long history, the river courses that have been filled with alluvial deposits have been hidden in the majority of the cases. This represents a risk when carrying out construction work in this type of environment. The deterioration of build-

Correspondence to: J. C. Hernández del Pozo

(jchdp@ugr.es) ings, as a result of laying foundations of this type of material, has been reported in cities such as Quito (Ecuador), Puebla (Mexico) and Cali (Colombia), amongst others (Velázquez, 1994; Velázquez, 1995; CENAPRED, 1999; Arizabaleta et al., 1981; Fernández, 1998; Granda et al., 2001; Soriano et al., 1995).

This study describes the application of dynamic penetration to measure the degree of consolidation and compaction. Used in conjunction with historical maps, this allows us to locate alluvial deposits and monitor their geographical evolution in urban environments, thereby providing us with information on the geo-technical impact of these deposits on buildings.

The study area that we have chosen is the River Beiro that flows through the historic city of Granada, a city that dates back to the Roman Era (González et al., 2002; Ubric, 2004; Pastor, 2004). The province of Granada is located in the south of Spain and forms a part of the region of Andalusia. The capital lies more or less in the centre of the province and has a population of around 250000 inhabitants. The area with which we are concerned lies towards the north of the city and takes in the entire route of the Beiro River through the city and the areas that come under its influence. The river is currently culverted (Fig. 1).

\section{Geological and geomorphological setting}

The city of Granada is located in the central area of the Betic Cordillera. This range is considered to be an area with significant interior tectonic activity (Galindo-Zaldivar et al., 1999). The Betic Cordillera and the Rif Mountains in Northern Africa represent the western terminus of the Alpine orogen. They are separated by the bed of the Alboran Sea, which consists of rocks that are similar to those found in the RifBetic range (Comas et al., 1992; Platt et al., 1998). The unique features of these westernmost Mediterranean chains are the result of their position between two large convergent plates - Africa and Europe - that have been exposed 


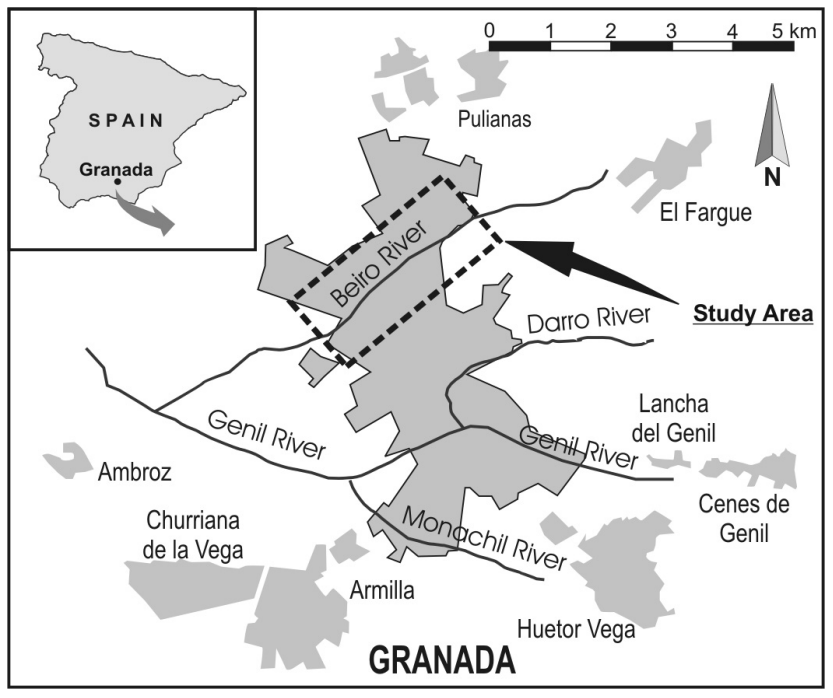

Fig. 1. Geographical location.

to variable directions of relative motion since the late Cretaceous (Dewey et al., 1989; Srivastava et al., 1990; Mazzoli and Helman, 1994; Morel and Meghraoui, 1996). The rocks of the Rif-Betic range are usually divided into three main zones: the Internal Zone, the External Zone and the Flysch Zone. The External Zone represents the passive continental margin of Iberia (García-Hernández et al., 1980). The Internal Zone consists of a stack of metamorphic nappes (Egeler and Simon, 1969) from the Palaeozoic to Triassic ages along with Neogene sedimentary basins. Thus, the different zones can be classified and described as follows (Fig. 2):

- The External Zone, consisting of rocks from the Mesozoic to Tertiary ages;

- The Flysch Zone, which mainly consists of Early Cretaceous to Early Miocene deep marine clastic deposits (Wildi, 1983);

- The Internal Zone, which is a tectonic environment with compressional structures and extensional structures (De Mets et al., 1990).

The Rif-Betic range also contains two other types of zone, although these areas are by no means as prevalent as the areas detailed above:

- Tertiary post-Orogenic basement;

- Neogenic-Cuaternary vulcanism.

Geochronologic data gathered from volcanic or subvolcanic rocks cropping out in the Betic and Rif Chains confirms that tholciitic magmas to calc-alkaline magmatism has accompanied the extensional processes (Torres-Roldán et al., 1986; Zeck et al., 1989; Monié et al., 1994; Bellon et al., 1983; Di Battistini et al., 1987; Hernández and Bellon, 1985; Hernández et al., 1987).

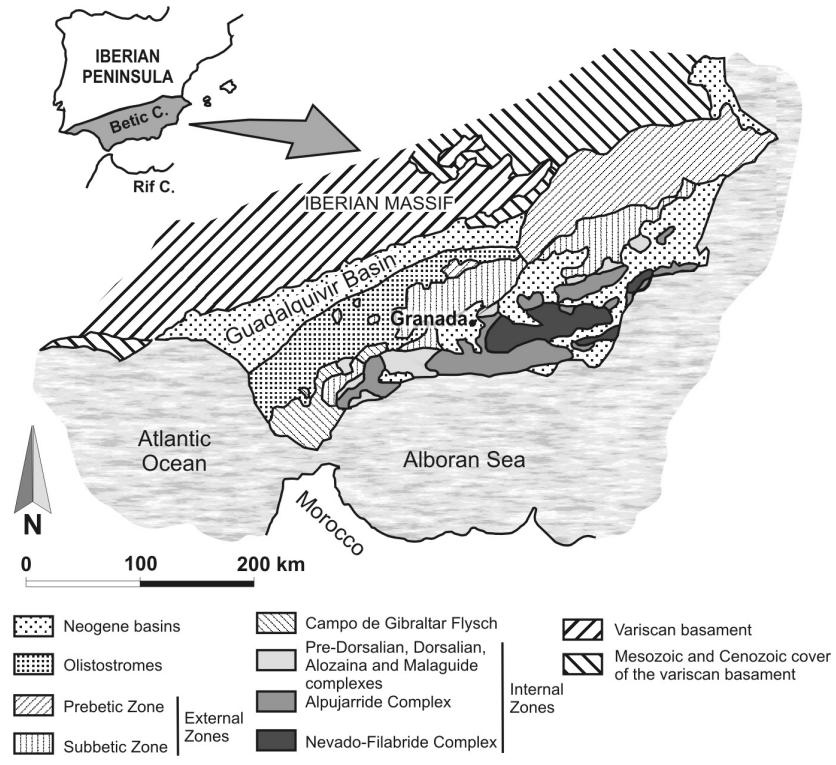

Fig. 2. Geological setting of the Betic and Rif Cordilleras within the framework of the western Mediterranean (Galindo-Zaldvar et al., 2003).

The Granada Basin, which is located in the centre of the Betic range, is one of these Neogene-Quaternary intramontane basins (Reicherter, 2001; Braga et al., 2003) and is one of the most seismically active zones of the Iberian Peninsula (Ruiz et al., 2003; Martín-Algarra et al., 2003). The sedimentary infill of the Granada Basin documents various NeogeneQuaternary tectonic and sedimentary phases. Shallow marine Tortonian-Messinian carbonate and evaporite facies are overlaid by terrigenous and lacustrine sediment, which, in turn, are succeded by Pliocene to Quaternary alluvial and colluvial sediments (Lhenaff, 1979; Gil-Zepeda, 2002).

The study area is located on the NE edge of the Granada basin. The bedrock in the area is a conglomeratic formation known as the Alhambra Formation, which dates back to the period between the Pliocene and Lower Pleistocene (Fig. 3). This formation is composed of alluvial fan deposits (Keller et al., 1996) and is covered by detritic sediments, of an alluvial nature, which date back to the Late Pleistocene (Ruiz et al., 2003). These sediments present many characteristics that are associated with processes arising from climatic change, which is highly representative of the Pleistocene. Lastly, during the Holocene, these materials were covered by alluvial sediments that can be linked to the activity of the fluvial network (Lupiani et al., 1988). In addition, it should be borne in mind that the city of Granada and its population have provoked many changes in the relief as a result of agricultural activity and urban planning.

\section{Systematic analysis of the technique}

The method we propose requires an extensive knowledge of the geotechnical properties of the area. This knowledge has 

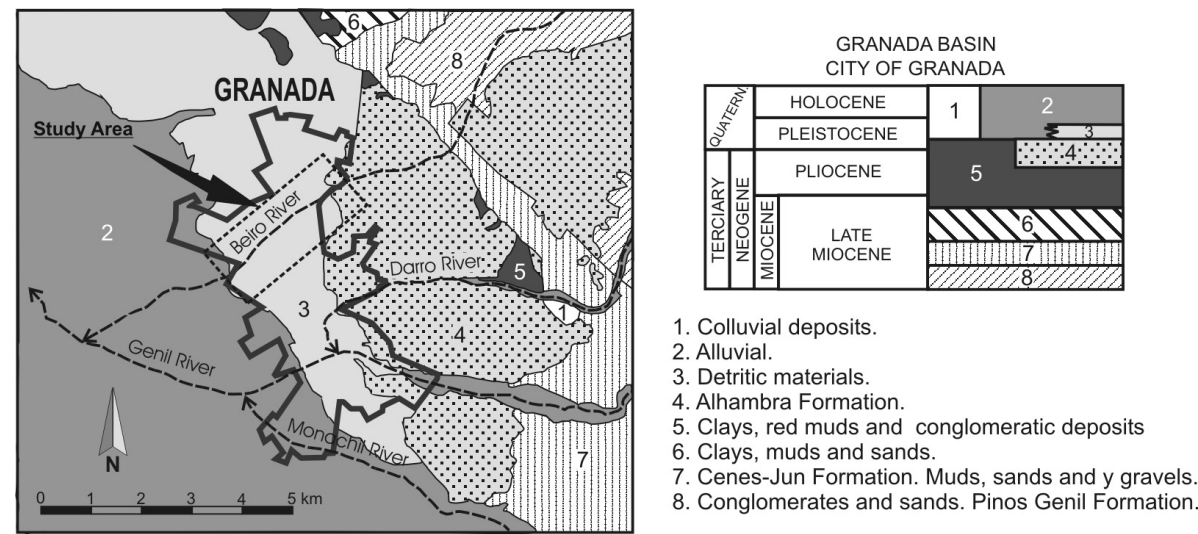

Fig. 3. Geological setting of the Granada City (Lupiani et al., 1988).

enabled us to identify the sedimentary sequence from the outset with a reasonable degree of accuracy. Observations made in this manner must be backed up by a significant number of field tests in order to demonstrate the feasibility of the method.

The system we employed may only be used when the boundary being sought lies between two materials with contrasting geotechnical properties.

We conducted the following field tests:

- Standard Classification of Soils for Engineering Purposes (Unified Soil Classification System), 2690 tests (ASTM D 2487-00);

- Standard Guide for selection of soil and rock sampling devices used with drill rings for environmental investigations (ASTM D 6169-98) and standard practice for thick wall, ring-lined, split barrel, drive sampling of soils (ASTM D 3550-01);

- Standard Test Method for Penetration Test and SplitBarrel Sampling of Soils (ASTM D1586-99).

Many other tests could have been used, including some that not only locate the boundary that we are seeking, but also provide information on its physical state. However, the tests we have used are the most common, given their ease of use and low cost. Thus, the large body of data obtained over the years by applying these tests in urban areas has proved useful in this case.

The method that we propose is extremely reliable when determining the depth below ground level at which a highly resistant stratum or level occurs, providing that this level lies below another level with a much lower resistance (Fletcher, 1965; Moretto et al., 1970; De Mello, 1971; Lacroix et al., 1973; Skempton, 1986; Liao, 1986).

In the event that there is a less marked difference in the physical properties of the strata, the boundaries are more difficult to identify, and research must be backed up by in-depth knowledge of the area and extensive statistics that identify what we refer to as the "transitional blows", or the number of blows registered at the boundary between one level and the next. The transitional blows identify the existence of an ambiguous area that lies between two different levels, where it is impossible to state whether we are dealing with one particular sediment type or the other. Clearly, the ideal situation would involve the existence of a substratum of rock underlying the network of rivers: in this case the transitional blow area would not exist and old river courses would be clearly identifiable.

This study model has an important application in the search for and discovery of the boundary that lies between highly compact and semi-soft sediments in urban systems, which would otherwise remain hidden by the edifications and infrastructures of the city. Our interest in studying the geotechnical impact of the River Beiro via this system, arises from the fact that this method is highly suited to the inherent characteristics of the area in question, which are outlined below:

- Significant levels of material with a low degree of competency in the areas that come under the influence of the river;

- These materials are the result of alternate beds of Holocene-age fine soil (mainly clays) and loamy clays interspersed with granules, which are not found in any of the other areas of the city of Granada;

- Thick beds of completely granular material from the Pleistocene age, which are much more competent, underlie the aforementioned soils;

- Many of the buildings that have been constructed in areas close to the river show physical signs of deterioration.

On the basis of these considerations we can draw the following conclusions:

- The materials making up the deposits that have filled the former course of the river, which are in some instances almost $16 \mathrm{~m}$ deep, were formed by soil that was eroded and then swept along by the river. 


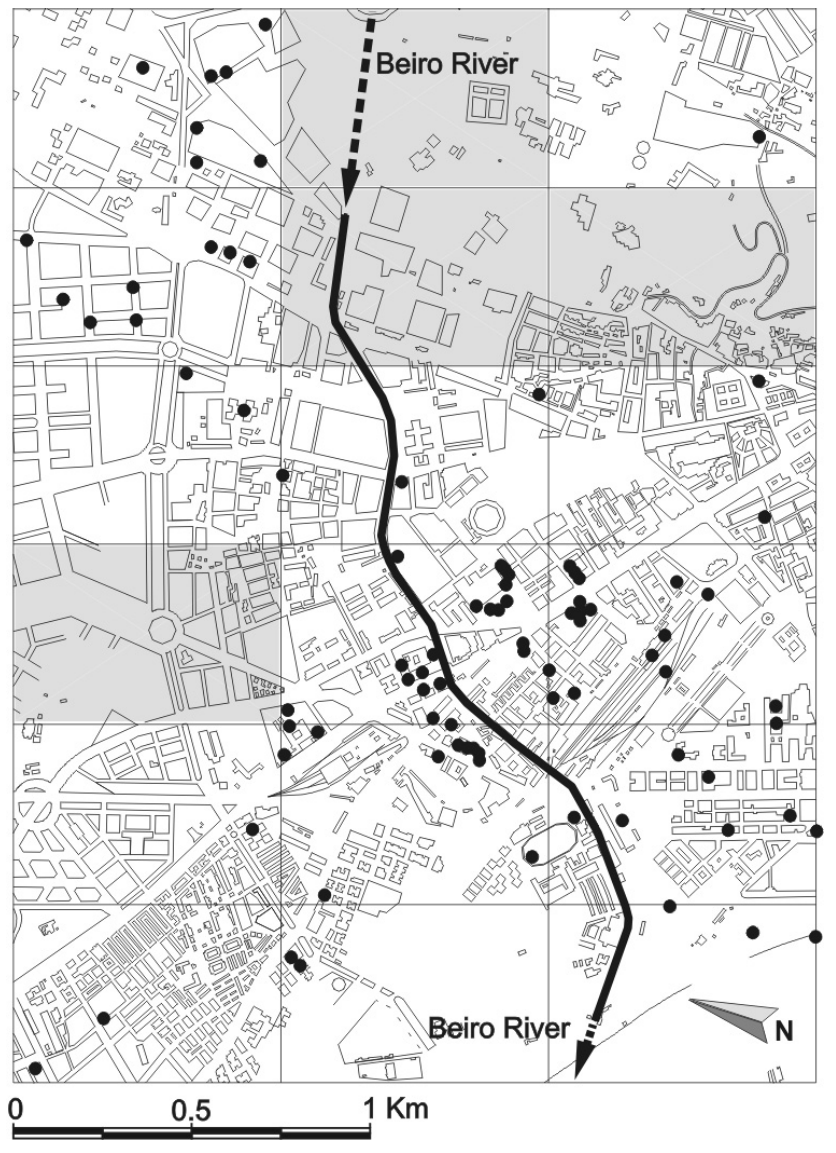

Fig. 4. Grid map of the study area indicating the location of the boreholes. The sections for which no data is available have been shaded. In addition, the map shows the current course of the River Beiro below the city.

- These sediments are unique when compared with the other sediment types in the city, as they are associated with the sediments deposited by the River Beiro;

- The materials that actually form the substratum in this area of the city consist of alluvial sand and gravel dating from the Late Pleistocene age;

- These granular sediments present a considerably higher degree of compaction when compared with the soil at higher levels (Holocene-age alluvial deposits);

- We believe that the deterioration of the buildings in the surrounding area is a direct result of the fact that their foundations rest on the aforementioned alluvial deposits.

\section{Application}

We have drawn up a map of the area that shows the course of the River Beiro and the surrounding area. This involves a surface area of $3000 \times 2250 \mathrm{~m}$ and we have indicated the sites of the boreholes that have provided data (Fig. 4), which data have been taken from 85 geotechnical studies that involved
190 test drillings and approximately 35 Borro-type continuous dynamic penetrations. The number of tests involved is equivalent to a borehole every $30000 \mathrm{~m}^{2}$. In other words, a borehole exists for each square section of approximately 180×180 m (Hernández, 1999).

The information we provide, whilst not exhaustive, is at the very least extremely comprehensive. The map divides the study area into a total of eighteen $750 \times 500 \mathrm{~m}$ blocks. Those blocks in which there is no available data have been labeled, and must be considered with a great deal of caution.

Given that we will be working with blow values, we have used the S.P.T. (Standard Penetration Test) value: any other values have been adapted to suit this model (Fig. 5). The proposed methodology should define a S.P.T. value for the transitional boundary between the fluvial deposits (Holocene age) and the underlying substratum in the area (Pleistocene age). On the basis of a large number of test drillings we have determined that S.P.T. values of between 25 and 35 correspond with what we have referred to as the transitional blows. On this basis we can state that higher S.P.T. values correspond with the underlying competent sediments of the River Beiro flood deposit area.

Using this data, we have drawn up a strata simulation map using depth isolines, which indicates the surface of the competent material that is currently buried beneath the alluvial deposits (Fig. 6). As the map shows, there are a total of six significant "depressions", which reach depths of up to $16 \mathrm{~m}$. Figure 7 is a three-dimensional representation of the results showing the resulting relief after the elimination of the aforementioned alluvial deposits. The diagrams obtained are the direct result of a mathematical interpolation using precise data obtained in the different field tests. The following package was used: M.D.T., Version 3, Revision 8, published by TCP-I.T. S.L. in 1998. The three-dimensional representation of the data allows us to identify those areas with a higher proportion of alluvial deposits.

The first conclusion that we can draw from these studies relates to the size of the sedimentation area of the river as it passes through the city of Granada: at one stage, the volume of flow of the river must have been much greater. Indeed, it must have been, if not the most important, then at least one of the most important rivers in the city area. This can be explained by the fact that, during the Holocene age, the sedimentation of fine soils gave way to an erosion phase, which was caused by the subsidence of the city and the simultaneous uplifting of the surrounding area (Lupiani et al., 1988). Moreover, the city of Granada has given rise to changes in the relief as a result of agricultural activity and urban planning, and rivers have been canalised since ancient times (Quesada, 1988). This has provoked a reduction of flooding with sediments and has accelerated the erosion process. In addition, extensive asphalted and built-up areas prevent infiltration and increase the flow rate of the river (Lupiani et al., 1988).

The second conclusion that can be drawn is that only a small section of the current course of the river coincides with the route that connects the depressions that have been detected. In the centre of the study area there are two 


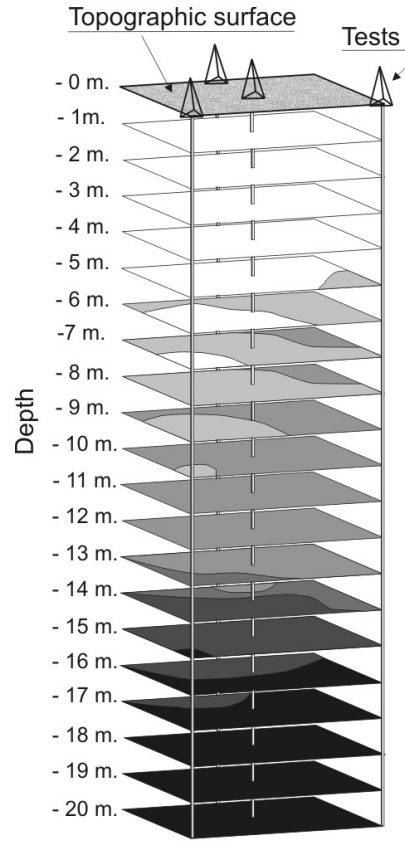

A

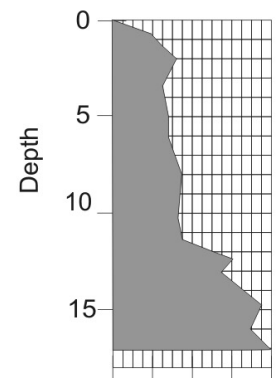

020406080 SPTs Values

B

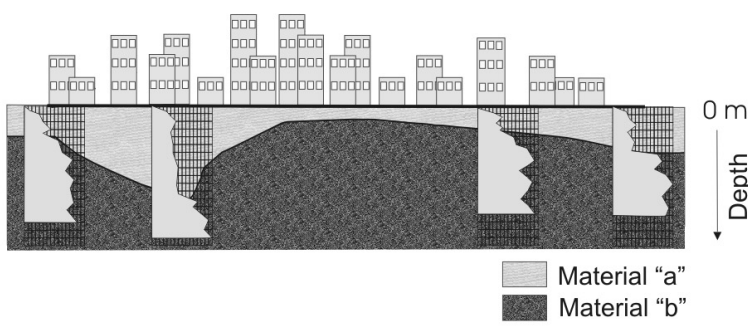

C

Fig. 5. (A) Three-dimensional representation illustrating the variation of SPT values in relation to depth. (B) Cross section with SPT values. (C) Differentiation in the materials as SPT values increase abruptly.

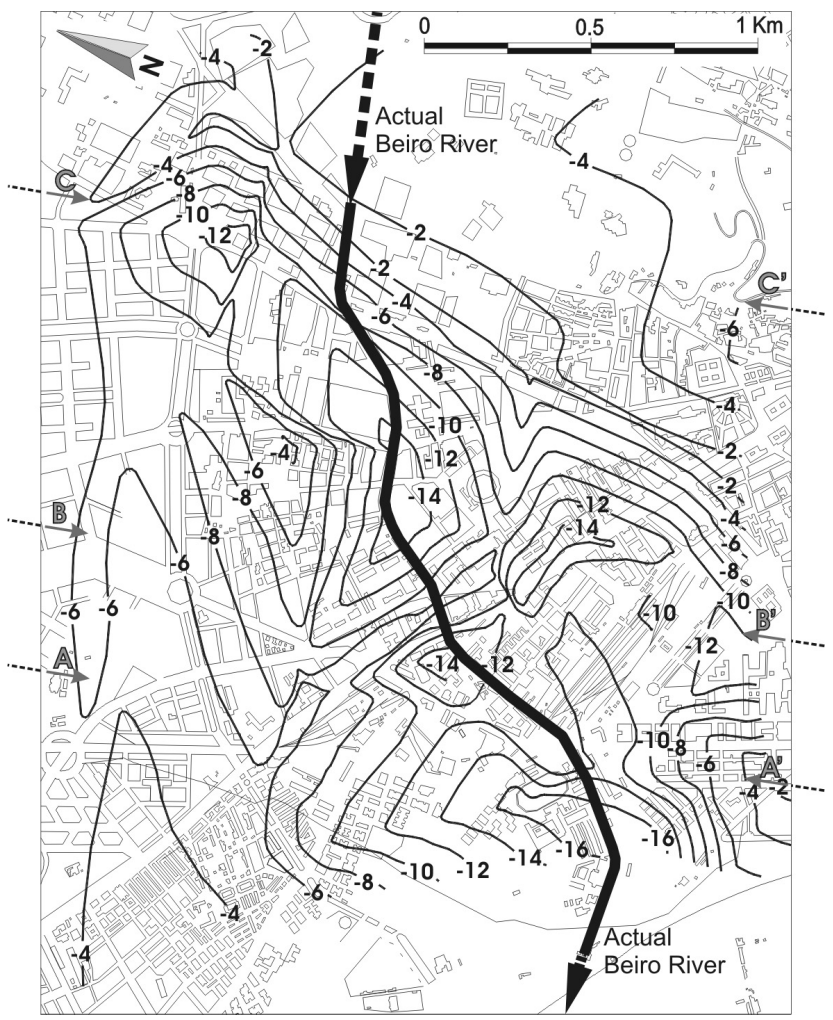

Fig. 6. Graphic representation of the substratum of the area or competent material with isolines of equal depth. The culverted course of the River Beiro through the city of Granada is indicated by a thick line.

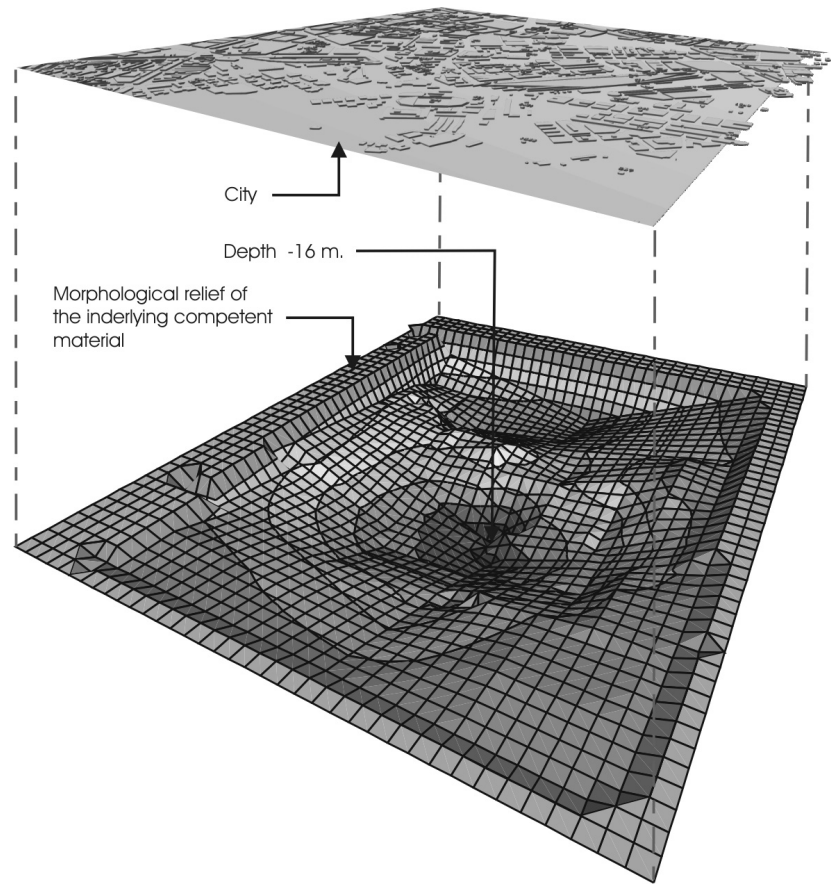

Fig. 7. Three-dimensional representation wherein we have generated the morphological relief of the underlying competent material that is present throughout the city of Granada (lower image). We have used this simulation to show a detailed representation of the study area (lower image). 


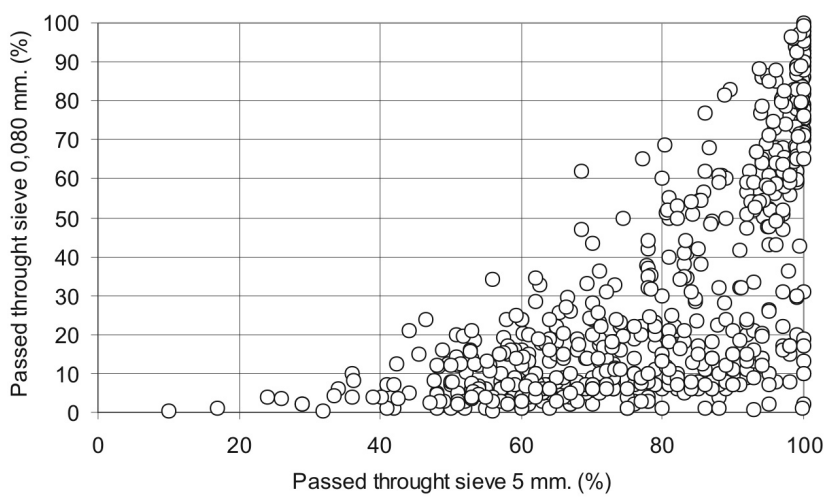

Fig. 8. Particle distribution according to size.

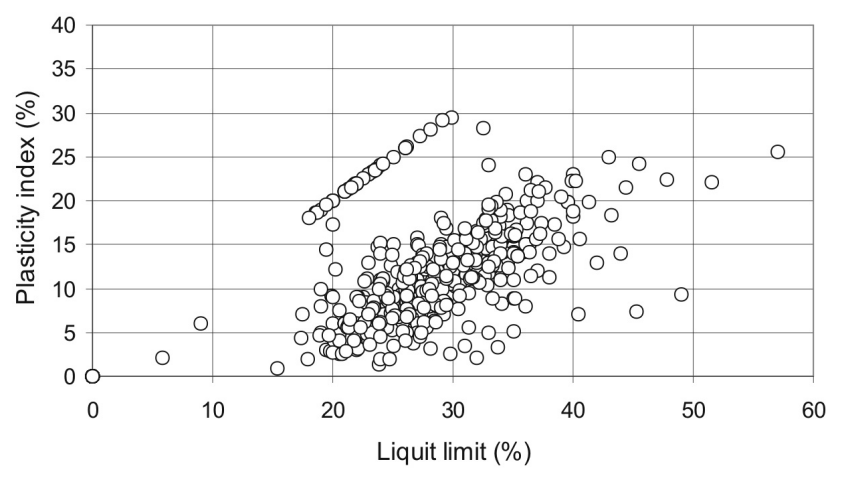

Fig. 9. Plasticity chart.

depressions of a depth of 15 and $17 \mathrm{~m}$ that have been filled by alluvial material.

Independent of the studies carried out up to this time, we carried out a comparative analysis of the materials, in order to confirm or reject the initial hypothesis of differentiation between the alluvial deposits (Holocene age) and the underlying level formed mainly of gravel and sand, which forms the substratum of the area (Pleistocene age). The granulometric values of the samples tested are shown in Fig. 8. A total number of 598 samples were tested. The plot of the data shows that there are two main groups: one formed of fine particles, corresponding to the soil deposited by alluvial means; the other group consists of larger particles, which corresponds with the substratum in the area under study.

The Atterberg Limit tests were carried out in accordance with the Standard Classification of Soils for Engineering Purposes (Unified Soil Classification System) (ASTM D 248700). A total of 737 tests were carried out (Fig. 9). In this case the values are equally decisive and differentiate two clearly defined groups. The first group is made up of clays and mud with low or medium plasticity, which correspond with the sediments deposited by the river (Holocene age). The second group is made up of values with very low or, in the majority of cases, zero limits, which correspond with the material forming the substratum in the area or the granular levels.

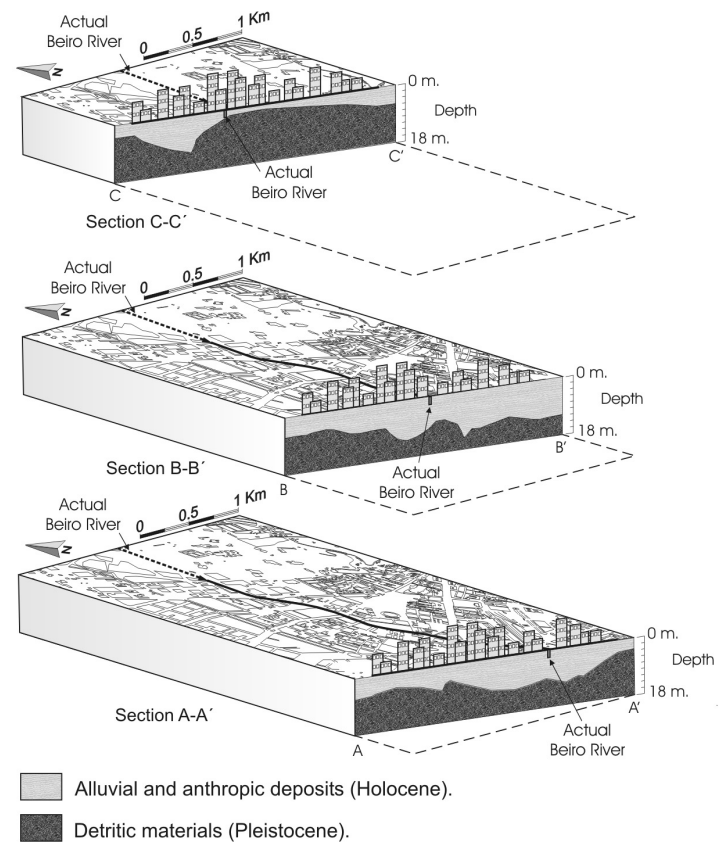

Fig. 10. Three-dimensional model of the area. The locations of the cross sections are indicated in Fig. 6.

Both tests, the granulometric tests and the Atterberg Limit tests, confirm the first interpretation of the stratigraphic sequence of the Beiro area and its surroundings. Any common geotechnical penetration system may prove suitable when attempting to determine the depths of lithological or compaction changes, providing that the variations are easily measured and display significant variations of resistance to penetration. The tests that we have carried out to locate risk zones make use of geological and geophysical reconnaissance techniques (Gocihico, 1990; Fitterman et al., 1991; Rogers et al., 1996; Miller et al., 1997; Maus et al., 1999; El-Hussain et al., 2000; Gourry et al., 2003).

In 1970, Ripoll identified former river courses in the city of Valencia using historical documentation and limited geotechnical data. Searches for former river courses via primarily geotechnical methods have been conducted by Brillinger (1985), who called attention to the need for detailed reconstruction of fluvial deposits under major cities, in order to safely and cost-effectively manage urban development. These areas often give rise to many different types of geotechnical problems, and therefore prior knowledge of the geographical situation within the urban layout is extremely useful.

The ideal situation, in the case of techniques based exclusively on penetrometric geotechnical reconnaissance, involves recently formed alluvial soils that present a medium or low degree of compaction, which rest upon soils with a higher degree of compaction as a result of their age or different composition. If the variation of resistance to penetration is identified, most methods of penetration will be able to provide reliable results when determining the depth at which the two different materials make contact. 

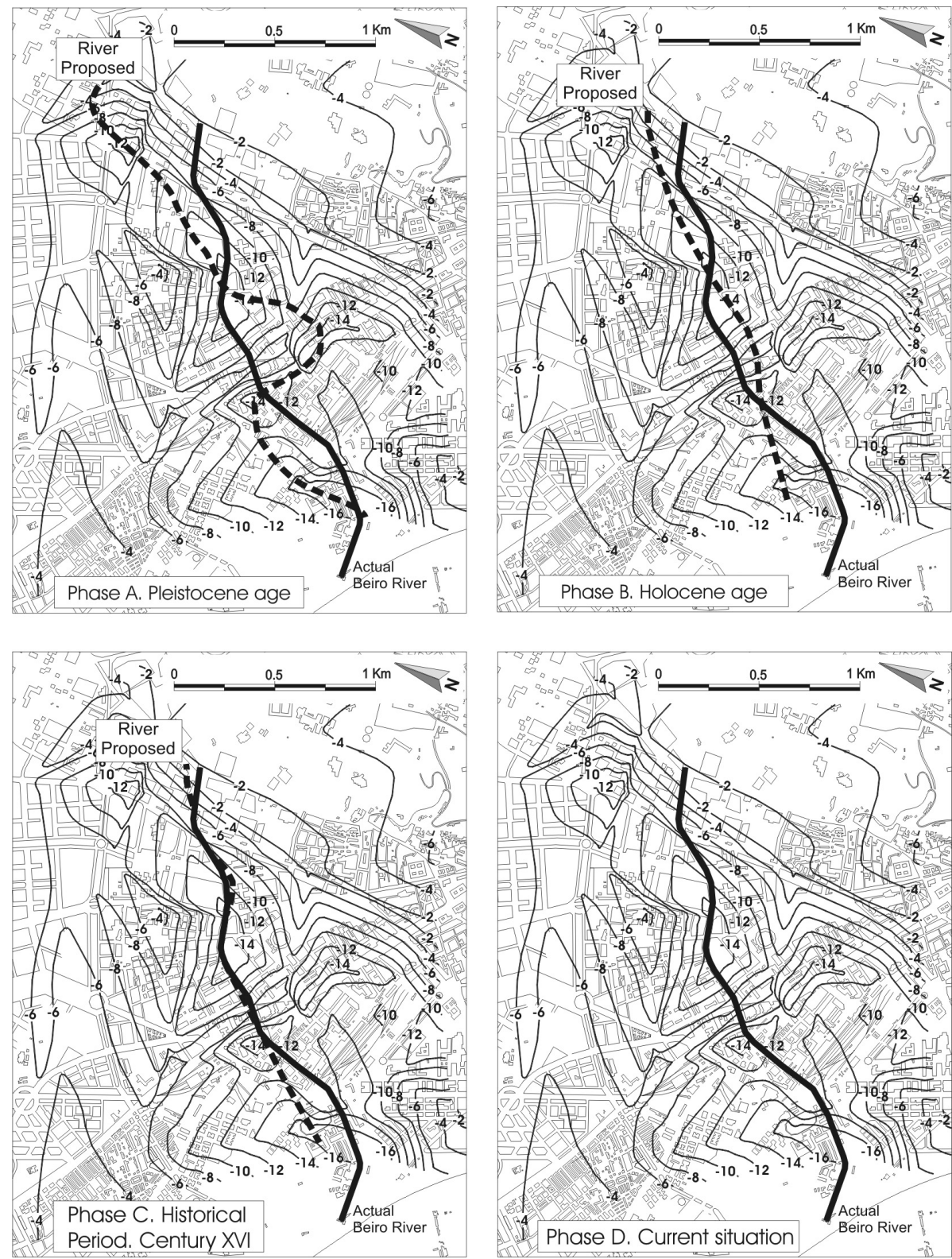

Fig. 11. Phases illustrating the evolution of the river.

This has proved to be the case with the River Beiro, lying west of the capital, which is currently canalised and covered as it passes through the city. The large number of penetrations in the area surrounding the river's course through the capital has allowed us to apply this methodology, wherein we initially determined the depth at which the base of the alluvial material of the river lies and subsequently produced a three-dimensional model.

The results obtained are highly illuminating, as detailed below:

- Firstly, the volume of this river valley (although the name of river is badly applied in view of its low or even inexistent water level) suggests a much higher volume of flow in the past (Fig. 10);
- The data obtained show that the current course of the river does not coincide with the old course of the river. At one point the course of the river must have been some $400 \mathrm{~m}$ to the west of its current course;

- From this point, the original course of the river flows through an area that is made up of thick alluvial deposits between 12 and $15 \mathrm{~m}$, and largely coincides with the current course of the river. Downstream, we find two hollows or basins, where we registered the thickest alluvial deposits $(17 \mathrm{~m})$;

- On the basis of the models we have made, we suggest that the evolution of the system can be split into 4 distinct phases (A-D). At the outset, the riverbed was made 


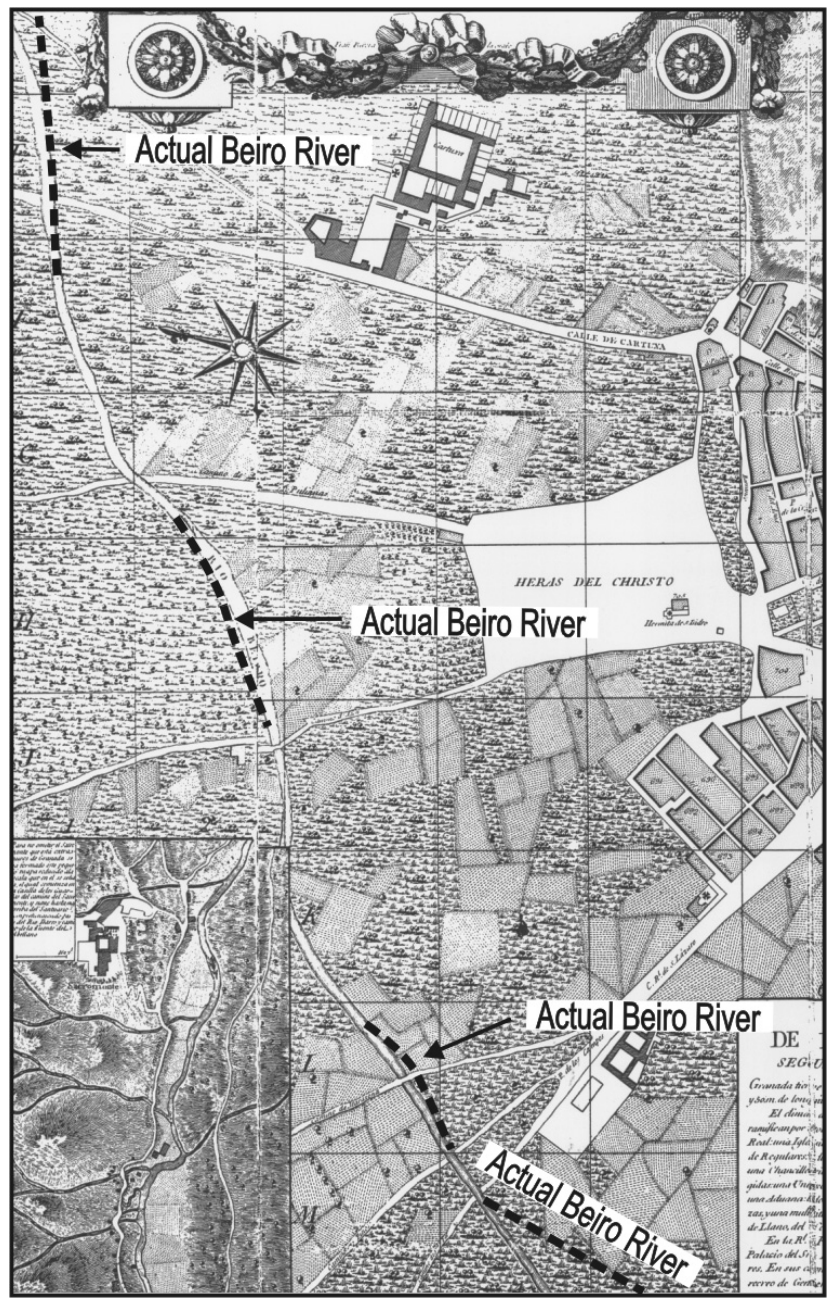

Fig. 12. Comparison of the current course of the river and the course as charted in 1796 (Topographical map of the city of Granada, Dalmau, 1796).

up of material from the Pleistocene age, and was meandriform in nature (Fig. 11, Phase A).

Subsequently (Fig. 11, Phase B), during the Holocene age, the meandriform stage gives way to a straight channel, as a result of the erosive capacity of the river during this period (Lupiani et al., 1988). The meandering ceased and the river flowed in a course that was straighter than the original course and that of the current course.

The first historical references that mention this river, and the now non-existent village that bore the same name, date back to the 14th century, although archaeological remains from the Roman era (contemporary with the reign of Emperor Vespasian, A.D. 69-79) have been found in the area (Fernández-Guerra, 1867).

In order to trace the possible variations in the course of the River Beiro over time, and corroborate any data that were obtained, we referred to one of the most well-known historic city maps of Granada: Dalmau's 1831 plan (Dalmau, 1796). We began by superimposing the current city plan onto the

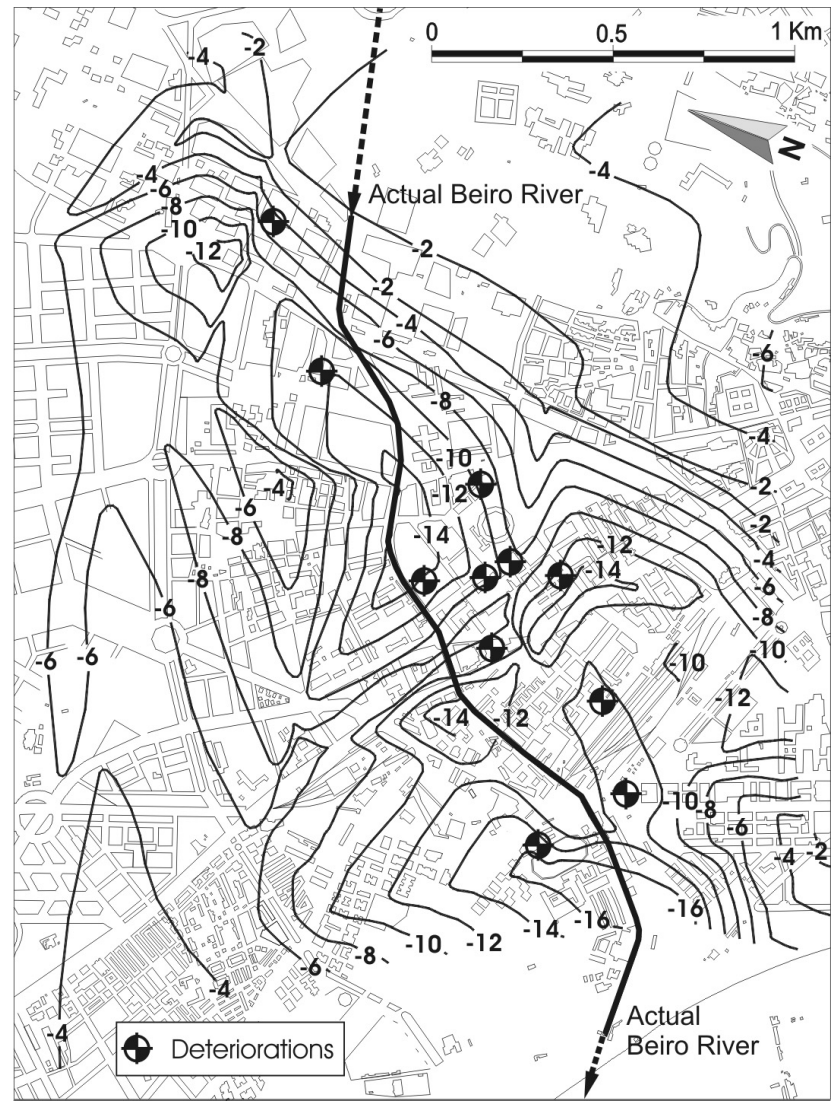

Fig. 13. Location of the buildings where deterioration has been observed.

historic plan using orthophotography, taking important buildings as axial points: the Cathedral, the Church of Santa Ana, and the Convent Del Carmen (Fig. 12).

We have observed that in the Western sector of the study area the current course of the river is separated from the former course by approximately $200 \mathrm{~m}$. Moreover, in the Eastern sector, the current course also varies in relation to the former course. This evolution is shown in Fig. 11, phase C, and coincides with our interpretations. Finally, the original course gradually comes closer to the current course of the River Beiro (Fig. 11, Phase D).

Clearly this interpretation of the evolution of the river must be backed up by other techniques that corroborate the location of the courses that have been identified. Nevertheless, the evolution we propose represents a starting point for further research.

The areas of Holocene-age alluvial deposits appear to coincide to a considerable degree with the areas wherein detrimental effects have been observed in buildings (Fig. 13). This fact can most easily be explained by the existence of significant alluvial deposits that have been used to support the foundations of the aforementioned buildings. These holocene-age sediments are cohesive are made up of and inorganic soils, generally soft loamy clays that are consolidated or in the process of consolidation. Whilst the bearing 

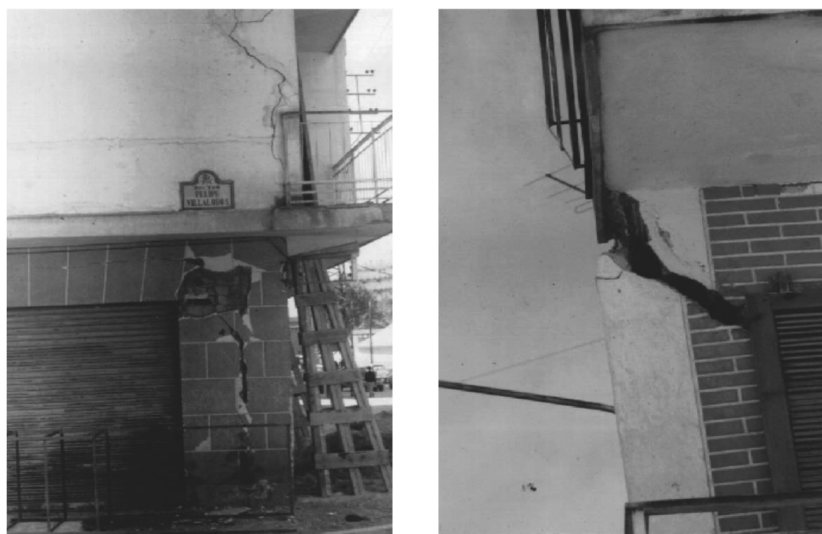

Fig. 14. Deterioration in a building in the Calle Pareja Yébenes, which led to the building being evacuated and demolished.

capacity may fall within acceptable levels, consolidation settlements and differentials are usually of great importance. In the study area pile foundations will have to be driven into the most competent material (Pleistocene).

The lack of damage to buildings in neighbouring areas provides further evidence to support the view that the damage to the buildings has been caused by the alluvial deposits. When the building boom occurred in the city of Granada between 1960 and 1970, it was common practice to build without a geotechnical report. The use of foundations that were adapted to granular soils in areas with alluvial deposits soon led to the appearance of detrimental effects due to sediments. In some cases the detrimental effects were so considerable that it was necessary to evacuate and demolish certain buildings at the beginning of the 1970s (Fig. 14), and we are still observing persistent damage in older buildings.

A catalogue or inventory of existing and corrected pathologies has been drawn up. The criteria proposed by Mañá, 1978; Cigni, 1976; Zelger, 1976; Croci, 1978 and Rodríguez, 1984 , were used to create the inventory. A total of thirtyone pathologies were identified in the buildings, of which eleven could be described as major (Fig. 13) and the remaining twenty as minor problems. We consulted the archives of several public institutions in Granada, and we interviewed the affected parties. In addition, we visited the various work sites where restoration is currently taking place. The classification of the pathologies is shown in Fig. 15.

The study shows that existing pathologies are not the result of the inherent edification defects, the construction system or the quality of the materials. Therefore, we can infer that we are dealing with a geotechnical problem that is attributable to two main causes:

- The buildings rest on soils with insufficient bearing capacity;

- Foundation support is not applied uniformly. This is mainly due to variations in the thickness of the compressible strata close to the foundation level.

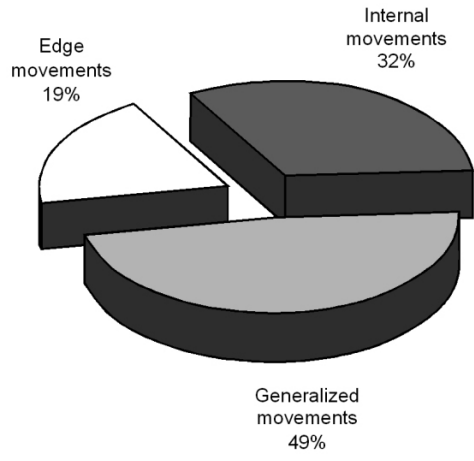

Fig. 15. Classification of the pathologies.

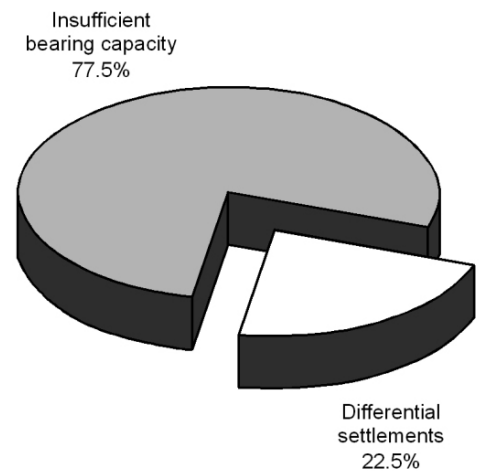

Fig. 16. Causes of the pathologies.

The causes that determine the pathologies under study are represented in Fig. 16.

During the course of the study we observed that the majority of the buildings in this area are composed of six storeys. In addition, existing documentation has shown that the foundations of these buildings were constructed via spread footing, with a length and width of $2 \mathrm{~m}$ in the vast majority of the cases, and with a bearing surface depth of $1 \mathrm{~m}$ (Fig. 17A).

On the basis of fifty-two direct shear tests under consolidated drained conditions (ASTM D 3080-03), we calculated the internal friction angles and cohesion of the different materials. Moreover, we measured the density of the soils via the Hydrostatic Balance Method (UNE 103-301-1994) (Fig. 17A).

Using these data a study was carried out to determine the settlements and limit pressures of the materials and the foundations wherein the thickness of the alluvial and anthropic deposits was variable (Figs. 17C and 17D). The peak value for the settlements was limited to $3.5 \mathrm{~cm}$ (NBE-AE, 1988), and from this point on buildings may be subject to pathologies. The values obtained are shown in Figs. 17B and 17C. Finally, we produced a comparative graph of the loads derived from the structures of the buildings on the basis of their heights (Fig. 17D)

On the basis of the calculations that were carried out and of the most frequent building typology (6 storeys) and foundation model in the area, we can classify the area into the following zones: 

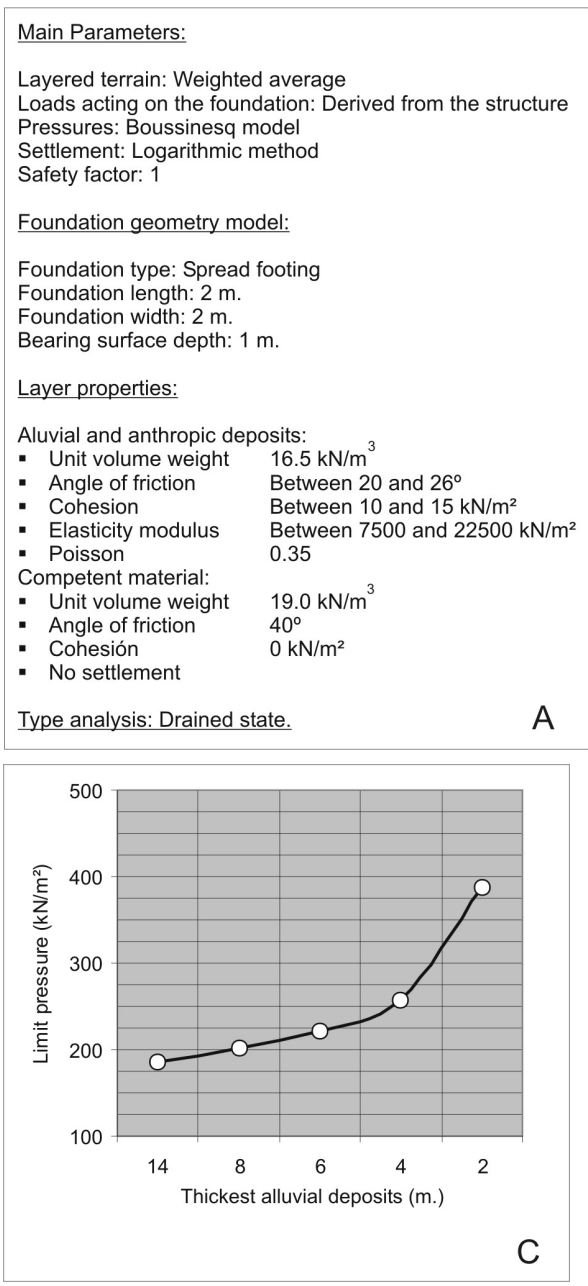
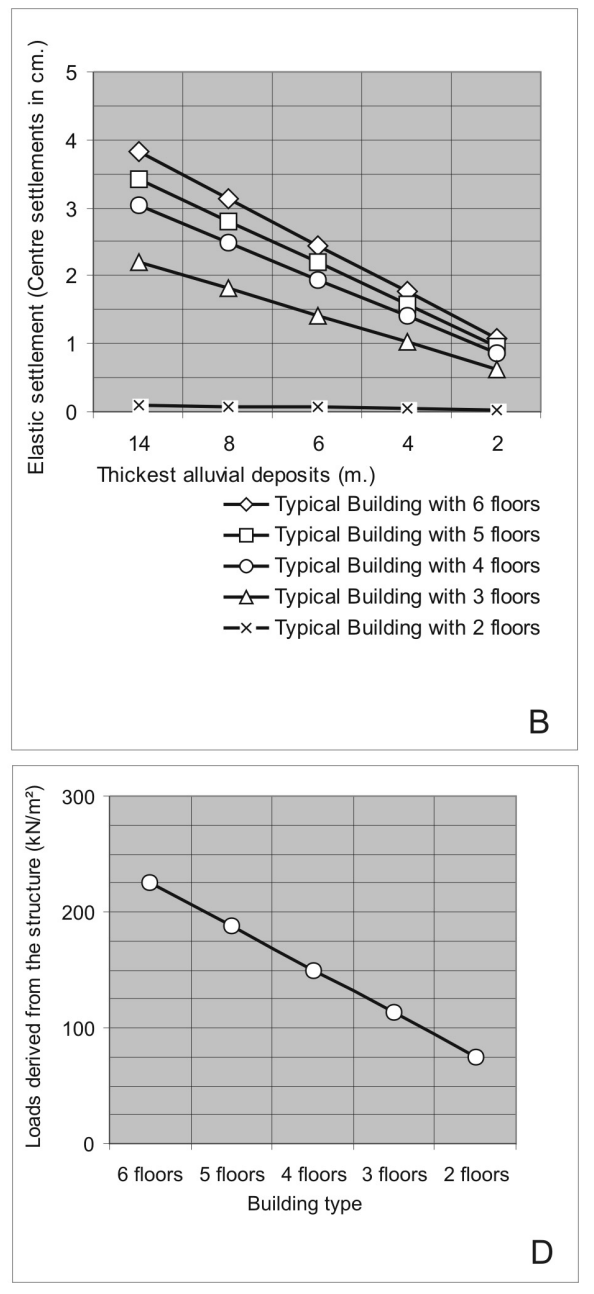

Fig. 17. (A) Main parameters. (B) Settlements. (C) Limit pressures. (D) Loads derived from the structures.

- Zones with thickest alluvial and anthropic deposits of between 14 and $8 \mathrm{~m}$ :

- These zones display significant settlements;

- Bearing capacity in these zones is very low.

- Zones with thickest alluvial and anthropic deposits of between 8 and $6 \mathrm{~m}$ :

- These zones display moderate settlements;

- Bearing capacity in these zones is low.

- Zones with thickest alluvial and anthropic deposits of less than $6 \mathrm{~m}$ :

- These zones display low settlements;

- Bearing capacity in these zones is acceptable.

The identification of these zones allows us to create a graphic representation of the risk of the appearance of pathologies in the buildings (Fig. 18), whereby the zone is divided into three areas:
- High Risk Area: Significant settlements and low bearing capacity caused by a considerable amount of recent alluvial and anthropic deposits. Possibility of the appearance of fissures, that advances at a rate of $1 \mathrm{~mm} / \mathrm{month}$. Zone with considerable social and economic repercussion as a result of this geotechnical problem;

- Moderate Risk Area: Low bearing capacities and moderate settlements. The social and economic repercussions of the model can be described as moderate. Probability of the appearance of fissures, that advances at a rate of between $1 \mathrm{~mm} /$ month and $1 \mathrm{~mm} /$ year;

- Low Risk Area: Settlements are generally insignificant and bearing capacity will range between suitable and moderate. Where fissures appear, their rate of advance is less than $1 \mathrm{~mm} /$ year. The socioeconomic implications of the problem will have little impact. 


\section{Conclusions}

The system and methodology that we have used, based on S.P.T. values (Standard Penetration Test), represent a useful and functional tool when defining areas of geotechnical risk, and in particular, when attempting to locate river courses that are currently hidden beneath the city, and which are filled by alluvial or anthropic deposits. In the case of the city of Granada, in the areas lying next to the River Beiro, we find zones of soft cohesive soils and zones made up of granular soils, which appear to occur erratically. The soft cohesive soils represent the alluvial deposits of the river during the Holocene age, which were deposited on top of the underlying competent bed that is mainly made up of granular materials (Pleistocene age). The geotechnical repercussion of these alluvial deposits on the subsoil of the city is clear. The model we propose has allowed us to detect these areas, which are currently hidden beneath asphalted and edified areas, and thereby identify the areas wherein buildings are exposed to high risk.

The technique used in the city of Granada may be able to explain and define the causes of some of the damage registered in the buildings, in particular when the buildings in question lie close to the current course followed by the river. This knowledge will allow us to calculate the risk of laying foundations in these areas, to adopt the appropriate measures and to warn of the need to carry out exhaustive reconnaissance testing of the subsoil.

Our results have allowed us to identify the existence of Holocene-age alluvial deposits that are the result of the activity of the Beiro River as it passes through the city of Granada. Up to now, geological cartographies made no reference to these materials, as they are hidden beneath roads and buildings. From a geological point of view, the work we have carried out has allowed us to complete existing cartographies by including these deposits in the study area. Lastly, we have defined the evolution of the River Beiro and surrounding area, using historic maps of the city of Granada, amongst other resources.

The technique we propose is clearly limited in that, in order to distinguish between two types of material, the materials in question must possess contrasting geological properties. This has proved to be the case in the study we have undertaken, wherein soft alluvial deposits rest on top of a bed of competent material.

The accuracy of the model we propose may be called into question due to the need to define S.P.T. values via what we referred to as the transitional blows. The transitional blows register the range of S.P.T. values that unquestionably mark the boundary between the alluvial deposits and the underlying competent bed. The accuracy of the results obtained depends upon the range of these transitional blows. Moreover, the effectiveness of the methodology we propose will be determined by the density, and the distribution and number of boreholes.

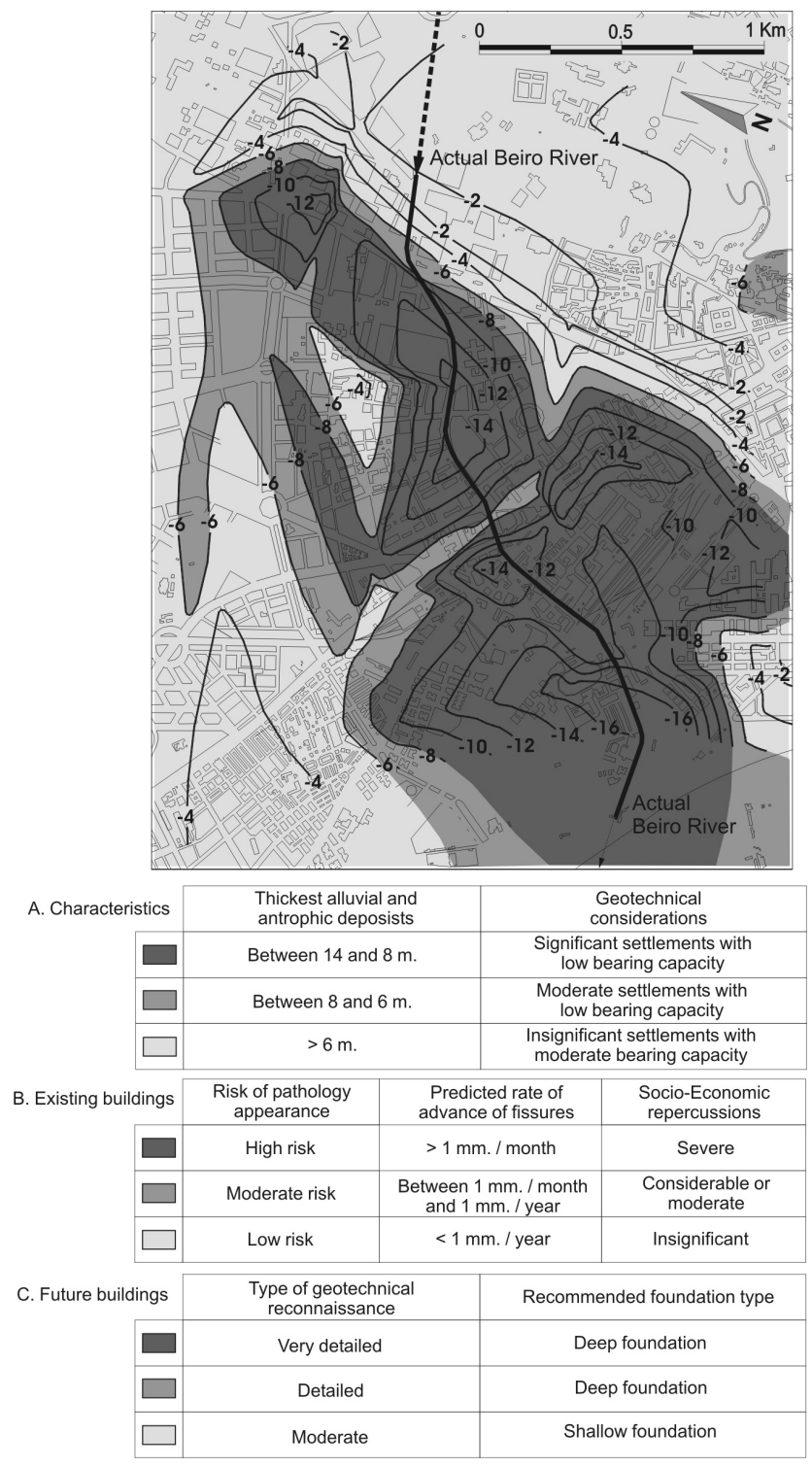

Fig. 18. Zones classified according to Risk of Pathology Appearance.

Acknowledgements. The authors wish to express their gratitude to the Company-University Foundation in Granada, which is dependent on the Ministry of Science and Technology, for the coordination that they carried out with the different companies and geo-technical laboratories with which they collaborate, in order to obtain field and laboratory data that was used in this paper. Without this data it would have been impossible to complete this study. We would also like to acknowledge the indispensable participation of G. McCune (B.A. Joint Honours, English/Spanish, Queen's University of Belfast) who translated this document from the original Spanish.

Edited by: F. Guzzetti

Reviewed by: K. Czuchlewski, V. Lapenna and two other referees 


\section{References}

Arizabaleta, M. T. and Santacruz, M.: Proceso Histórico del Desarrollo Urbano de Cali, in: Santiago de Cali, 450 años de historia. Dirección de Comunicaciones, Alcaldía de Santiago de Cali, Editorial XYZ, Cali, 1981.

ASTM: Standard Practice for Thick Wall, Ring-Lined, Split Barrel, Drive Sampling of Soils, D3550-98, Annual book of ASTM Standards, 2004, Section 4: Construction, Volume 04.08, Soil and Rock, ASTM, Philadelphia, PA, 1998.

ASTM: Standard Test Method for Penetration Test and Split-Barrel Sampling of Soils, D1586-99, Annual book of ASTM Standards, 2004, Section 4: Construction, Volume 04.08, Soil and Rock, ASTM, Philadelphia, PA, 1999.

ASTM: Standard Classification of Soils for Engineering Purposes (Unified Soil Classification System), D2487-00, Annual book of ASTM Standards, 2004, Section 4: Construction, Volume 04.08, Soil and Rock, ASTM, Philadelphia, PA, 2000.

ASTM: Standard Guide for selection of soil and rock sampling devices used with drill rings for environmental investigations, D6169-98, Annual book of ASTM Standards, 2004, Section 4: Construction, Volume 04.09, Soil and Rock (II), ASTM, Philadelphia, PA, 2001.

ASTM: Standard Test Method for Direct Shear Test of Soils Under Consolidated Drained Conditions, D3080-03, Annual book of ASTM Standards, 2004, Section 4: Construction, Volume 04.08, Soil and Rock, ASTM, Philadelphia, PA, 2003.

Bellon, H., Bordet, P., and Montenat, C.: Le magmatisme néogène des Cordillères Bétiques (Espagne): cronologie et principaux caractères géochimiques, Bull. Soc. Geol. Fr., Ser. 7, 25, 205218, 1983.

Braga, J. C., Martín, J. M., and Quesada, C.: Patterns and average rates of late Neogene-Recent uplift of the Betic Cordillera, SE Spain, Geomorpology, 50, 3-26, 2003.

Brillinger, A. B.: Investigation of Trinity River Paleochannels in the Central Busines District, Dallas, Texas. Master's Thesis, Department of Geology, Texas A\&M University, College Station, 1985.

Brillinger, A. B.: Student Professional Paper: Graduate Division: Mapping Paleochannels in Fluvial Deposits Through the Application of Geotechnical Stratigraphy, 1986, XXIII, 1, 5, 1985.

CENAPRED: Centro Nacional de Prevención de Desastres: Informe del Sismo de Tehuacán, Puebla el 15 de Junio de 1999, Mexico, 1999.

Cigni, G.: Consolidamento e ristrutturazione dei vecchi edifici, Ed. Kappa, Univ. de Roma, Fac. d'Arch, 1976.

Comas, M. C., García-Dueñas, V., and Jurado, M. J.: Néogène tectonic evolution of the Alboran Sea from MCS data, Geo-Marine Lett., 12, 157-164, 1992.

Croci, G.: Pevenzione dei Disesti e Consolidamento Strutturale, Pioda, Roma, 1978.

Dalmau, F.: Mapa Topográfico de la Ciudad de Granada, Archivo histórico municipal de Granada, 1796.

De Mello, V. F. B.: The Standard Penetration Test. Proceedings of the 4th Panamerican Conference on Soil Mechanics and Foundation Engineering: San Juan, PR, 1, 1-86, 1971.

De Mets, C., Gordon, R. G., Argus, D. F., and Stein, S.: Current plate motions, Geophys. J. Int., 101, 425-478, 1990.

Dewey, J. F., Helman, M. L., Turco, E., Hutton, D. H. W., and Knott, S. D.: Kinematics of the western Mediterranean, in: Coward, M. P., 1989.

Di Battistini, G., Toscani, L., Iaccarino, S. and Villa, I. M.: K/Ar ages and the geological setting of calc-alkaline volcanic rocks from Sierra de Gata, SE Spain, Neues Jahrb. Mineral., 8, 369383, 1987.

Egeler, C. G. and Simon, O. J.: Sur la tectonique de la zone Bétique (Cordillères Bétiques, Espagne), Proceedings van de Koninklijke Nederlandse Akademie voor Wetenschappen, Afdeling Natuurkunde, eerste reeks 25, 1-90, 1969.

El-Hussain, I., Holbrook, J., and Sneed, C.: Integrating geophysical and geological methods to delineate buried paleochannels in the New Madrid seismic zone of southeastern Missouri, in: Proceedings of the Symposium on the Application of Geophysics to Engineering and Environmental Problems, edited by: Powers, M. H., et al., 20-24 February 2000, Wheat Ridge, Colo., Environmental and Engineering Geophysical Society, 253-262, 2000.

Fernández-Guerra, A.: Epigrafía romano granadina, Carta de Aureliano Fernández-Guerra, Alicante: Biblioteca Virtual Miguel de Cervantes, 1867.

Fernández, M. A.: Zonificación de amenazas naturales y reglamentación urbana en Quito, Ecuador. Navegando entre brumas, La Aplicación de los Sistemas de Información Geográfica al Análisis de Riesgo en America Latina. Editor Andrew Maskrey Estudios Sociales en Prevención de Desastres en América Latina (LA RED), 1989.

Fitterman, D. V., Menges, C. M., Al Kamali, A. M., and Jama, F. E.: Electromagnetic mapping of buried paleochannels in eastern Abu Dhabi Emirate, U.A.E., Geoexploration, 27, 111-133, 1991.

Fletcher, G. F. A.: Standard Penetration Test: Its Uses and Abuses. Journal Soil Mechanics \& Foundations. Div., ASCE, 91, SM4, 67-75, 1965.

Galindo-Zaldívar, J., Jabaloy, A., Serrano, I., Morales, J., GonzálezLodeiro, F., and Torcal, F.: Recent and present-day stresses in the Granada Basin (Betic Cordilleras): example of a late Miocenepresent-day extensional basin in a convergent plate boundary, Tectonics, 18, 686-702, 1999.

Galindo-Zaldivar, J., Gil, A. J., Borque, M. J., Gonzalez-Lodeiro, F., Jabaloy, A., Marín-Lechado, C., Ruano, P., and Sanz de Galdeano, C.: Active faulting in the internal zones of the central Betic Cordilleras (SE, Spain), J. Geodyn., 36, 239-250, 2003.

García-Hernández, M., López-Garrido, A. C., Rivas, P., Sanz de Galdeano, C., and Vera, J. A.: Mesozoic paleographic evolution of the External Zones of the Betic Cordilleras, Geologie en Mijnbouw, 59, 155-168, 1980.

Gil-Zepeda, S. A., Luzón, F., Aguirre, J., Morales, J., SánchezSesma F. J., and Ortiz-Alemán, C.: 3D Seismic Response of the Deep Basement Structure of the Granada Basin (Southern Spain), Bulletin of the Seismological Society of America, 92, 2163-2176, 2002.

Gocihico, L.: High resolution seismic survey to map paleochannels in an underground coal mine, Canadian Journal of Exploration Geophysics, 26, 87-93, 1990.

González, C.: Ciudad y privilegio en Andalucía en época romana, Universidad de Granada, 2002.

González, C. and Padilla, A.: Estudios sobre las ciudades de la Bética, Universidad de Granada, 2002.

Gourry, J. C., Vermeersch, F., Garcia, M., and Giot, D.: Contribution of Geophysics to the Study of Alluvial Deposits: A Case Study in the Val d'Avaray Area of the River Loire, France, J. Appl. Geophys., LIV (2003, 1), 35-49, 2003.

Granda, A. and Cambero, J. C.: Algunas experiencias de la aplicación de métodos geofísicos en los proyectos geotécnicos y constructivos de la L. A. V. Madrid-Barcelona-Frontera Francesa, tramo Madrid-Zaragoza, Ingeniería Civil, 123, 15-29, 2001. 
Hernández, J. and Bellon, H.: Chronologie K-Ar du volcanisme miocéne, Rev. Geol. Geogr. Phys., 26, 85-94, 1985.

Hernández, J., De Larouzière, F. D., Bolze, J., and Bordet, P.: Le magmatisme néogène bético-rifain et le couloir de cécrochement trans-Alboran, Bull. Soc. Geol. Fr., 3, 257-267, 1987.

Hernández, J. C.: Análisis metodológico de la cartografía geotécnica urbana aplicada a la Ciudad de Granada. Universidad de Granada, Inedited, 1999.

Keller, E. A., Sanz de Galdeano, C., and Chacón, J.: Tectonic geomorphology and earthquake hazard of Sierra Nevada, South Spain, in: Proceedings of the 1 Conferencia Internacional Sierra Nevada, Granada, Spain, March 1996, 201-218, 1996.

Lacroix, Y. and Horn, H.: Direct Determination and Indirect Evaluation of Relative Density and Its Use on Earthwork Construction Projects: in Evaluation of Relative Density and Its Role in Geotechnical Projects Involving Cohesionless Soils, ASTM Special Technical Publication, 523, 251-280, 1973.

Lhenaff, R.: Le basin de Grenade (Andalousie, Espagne): Morphogenèse d'une cuvette intra-montagneuse, Mediterranée, 3, 37-44, 1979.

Liao, S. S. C. and Whitman, R. V.: Overburden Correction Factors for SPT in Sand, Journal of Geotechnical Engineering, A.S.C.E., 112, 373-377, 1986.

Lupiani, E. and Soria, J.: Mapa Geológico de España. Granada, Instituto Geológico y Minero de España, 1090, 19-41, 1988.

Mañá, F.: Patología de las cimentaciones, edited by: Blume, 117 pp., 1978.

Martín-Algarra, A., Martín-Martín, M., Andreo, B., Julià, R., and González-Gómez, C.: Sedimentary patterns in perched spring travertines near Granada (Spain) as indicators of the paleohydrological and paleoclimatological evolution of a karst massif, Sedimentary Geology, 161, 217-228, 2003.

Maus, S., Sengpiel, K. P., Röttger, B., Siemon, B., and Tordiffe, E. A. W.: Variogram analysis of helicopter magnetic data to identify paleochannels of the Omaruru River, Namibia, Geophysics, 64, 785-794, 1999.

Mazzoli, S. and Helman, M.: Neogene patterns of relative plate motion for Africa-Europe: some implication for recent central Mediterranean tectonics, Geol. Rundsch., 83, 464-468, 1994.

M.D.T.: User Manual, Ver. 3., Rev. 8., TCP-I.T., S.L., 1998.

Miller, R. D. and Xia, J.: Delineating paleochannels using shallow seismic reflection, The Leading Edge, 16, 1671-1674, 1997.

Monié, P., Torres-Roldán, R. L., and García-Casco, A.: Cooling and exhumation of the western Betic Cordilleras, 40Ar/40Ar thermochronological constraints on a collapsed terrane, Tectonophysics, 238, 353-379, 1994

Morel, J. L. and Meghraoui, M.: Gorringe-Alboran-Tell tectonic zone: a transpression system along the Africa-Eurasia plate boundary, Geology, 24, 755-758, 1996.

Moretto, V.: The Dynamic Penetration Test: A Standard That is not Standardized, Geotechnique, 20, 185-192, 1970.

NBE-AE: Acciones en la edificación. Asientos generales admisibles según la Norma de acción en la edificación, NBE-AE-88, 1988.

Pastor, M.: Sociedad y Epigrafía en Granada en época romana, Universidad de Granada, 2004

Platt, J. P., Soto, J. I., Whitehouse, M. J., Hurford, A. J., and Kelley, S. P.: Thermal evolution, rate of exhumation and tectonic significance of metamorphic rocks from the floor of the Alboran extensional basin, western Mediterranean, Tectonics, 17, 671-689. 1998.

Quesada, M. D.: El repartimiento nazarí del río Beiro (siglo XIV), Andalucía entre Oriente y Occidente (1262-1492), Actas del
V Coloquio Internacional de Historia Medieval de Andalucía, Córdoba, España, 699-705, 1988.

Reicherter, K. R.: Paleoseismologic advances in the Granada Basin (Betic Cordilleras, southern Spain), Acta Geologica Hispana, 36, 267-281, 2001.

Ripoll, J. L.: Problemas de cimentaciones en la región de Valencia, I Jornadas Técnicas Nacionales de Cimentaciones, 283-288, 1969.

Rodríguez Ortiz, J. M.: Curso de Rehabilitación. 4, La Cimentación. Servicio de Publicaciones del Colegio Oficial de $\mathrm{Ar}$ quitectos de Madrid (COAM), 1984.

Rogers, N. T., Sandberg, S. K., and Powell, G.: The Effective Use of Electromagnetic Methods to Delineate a Fluvial Paleochannel System Controlling Oil Migration near Glenrock, Wyoming, in: Proceedings of the Symposium on the Application of Geophysics to Engineering and Environmental Problems: SAGEEP‘96, 28 April-2 May 1996 (Wheat Ridge, Colorado: Environmental and Engineering Geophysical Society, 1996), 917-26, 1996.

Ruiz, A. M., Ferhat, G., Alfaro, P., Sanz de Galdeano, C., De Lacy, M. C., and Rodriguez-Caderot, A. J.: Geodetic measurements of cristal deformation on NW-Se faults of the Betic Cordillera, southern Spain, 1999-2001, J. Geodyn., 35, 259-272, 2003.

Skempton, A. W.: Standard Penetration Test Procedures and the Effects in Sands of Overburden Pressure, Relative Density, Particle Size, Aging and Overconsolidation, Geotechnique, 36, 425-447, 1986.

Soriano, M. A. and Simón, J. L.: Alluvial dolines in the central Ebro Basin, Spain: a spatial and developmental hazard analysis, Geomorphology, 11, 295-309, 1995.

Srivastava, S. P., Schouten, H., Roest, W. R., Klitgord, K. D., Kovacs, L. C., Verhoef, J., and Macnab, R.: Iberian plate kinematics: a jumping plate boundary between Eurasia and Africa, Nature, 344, 756-759, 1990.

Torres-Roldán, R. L., Poli, G., and Peccerillo, A.: An early Miocene arc-tholeiitic magmatic dike event from the Alboran-Sea: evidence for precollisional subduction and back-arc crustal extension in the western-most Mediterranean, Geol. Rundsch., 75, 219-234, 1986.

Ubric, P.: La Iglesia en la Hispania del siglo V, Granada, Universidad de Granada, 2004.

UNE: Determination of soil density. Hydrostatic Balance Method, UNE 103-301-94, Norma Española. Asociación Española de Normalización y Certificación (AENOR), 1994.

Velázquez, A.: Desastres y Sociedad, No. 5, Año 3, Especial: La Sequía en el Nordeste del Brasil, Revista semestral de la red de estudios sociales en prevención de desastres en América Latina, 1995.

Velázquez, A. and Meyer, H.: Ofertas y amenazas ambientales en Cali. Santiago de Cali, Universidad del Valle, Observatorio Sismológico del Surccidente-OSSO, Publicaciones ocasionales del OSSO, No. 3, 1994

Wildi, W.: La chaine tello-rifaine (Algérie, Maroc, Tunisie): structure stratigraphie et évolution du Trias au Miocène, Revue de Géologie Dynamique et de Géographie Physique, 24, 201-297, 1983.

Zeck, H. P., Albat, F., Hansen, B. T., Torres Roldán, R. L., García Casco, A., and Martín Algarra, A.: A 21 2 Ma age for the termination of the ductile Alpine deformation in the internal zone of the Betic Cordilleras, south Spain, Tectonophysics, 169, 215220, 1989

Zelger, C.: Beobachtung von Rissen in Bauwerken, Die Bautechnik, 11, 361-372, 1976. 